\title{
Evidence that GLUT-2 mRNA and protein concentrations are decreased by hyperinsulinaemia and increased by hyperglycaemia in liver of diabetic rats
}

\author{
Rémy BURCELIN, ${ }^{*}$ Mohamed EDDOUKS, $\dagger$ Joseph KANDE, ${ }^{*}$ Roger ASSAN $\dagger$ and Jean GIRARD* \\ ${ }^{*}$ Centre de Recherche sur l'Endocrinologie Moléculaire et le Développement, CNRS, 9 rue Jules Hetzel, 92190 Meudon-Bellevue, \\ and †Service de Diabétologie, Hôpital Bichat, 16 rue Huchard, 75018 Paris, France
}

\begin{abstract}
GLUT-2, glucokinase (GK) and phosphoenolpyruvate carboxykinase (PEPCK) mRNA expression was studied in the liver of chronically catheterized diabetic rats during the 3 days after an intravenous injection of $65 \mathrm{mg}$ of streptozotocin (STZ) $/ \mathrm{kg}$. At $6 \mathrm{~h}$ after the STZ injection, portal plasma insulin levels were $270 \pm 32 \mu$-units $/ \mathrm{ml}$ and blood glucose was $1.4 \pm 0.4 \mathrm{mmol} / 1$, owing to pancreatic $\beta$-cell destruction. GLUT-2 and PEPCK mRNA concentrations were rapidly and dramatically decreased $(>90 \%$ ), whereas GK mRNA was increased. After $30 \mathrm{~h}$, plasma insulin concentrations were lower than $5 \mu$-units $/ \mathrm{ml}$ and blood glucose was $>20 \mathrm{mmol} / 1$. GLUT-2 and PEPCK mRNA concentrations increased 2fold and GK mRNA disappeared progressively. In order to assess the relative roles of hyperglycaemia and insulinopenia, blood glucose was clamped at $6.4 \pm 0.5 \mathrm{mmol} / 1$ from 18 to $72 \mathrm{~h}$ after STZ injection by phlorizin infusion $(0.5-2 \mathrm{~g} / \mathrm{day}$ per $\mathrm{kg}$ ) or at $6.6 \pm 0.3 \mathrm{mmol} / 1$ from 18 to $48 \mathrm{~h}$ after STZ injection by insulin infusion ( $0.25 \mathrm{unit} / \mathrm{min} \mathrm{per} \mathrm{kg}$ ). GLUT-2 mRNA concentrations were $50 \%$ lower in phlorizin-infused than in untreated diabetic rats. The low levels of GK mRNA and the high levels of PEPCK mRNA were unaffected by normalization of hyperglycaemia in phlorizin-infused diabetic rats. In insulin-infused rats (portal plasma insulin levels of $40 \mu$-units/ml) GLUT- 2 mRNA levels were $25 \%$ of those in untreated diabetic rats, and they increased rapidly $6 \mathrm{~h}$ after insulin infusion was stopped. Liver GLUT-2 protein concentration showed similar changes in response to STZ injection and to phlorizin or insulin treatment, but after a delay of several hours. From this work we conclude that GLUT- 2 gene expression is dramatically and rapidly $(<6 \mathrm{~h})$ decreased by portal hyperinsulinaemia and increased by hyperglycaemia.
\end{abstract}

\section{INTRODUCTION}

Glucose homoeostasis is a tightly regulated phenomenon that involves glucose uptake by peripheral tissues and glucose storage by, or production from, the liver. The transport of glucose into the cell represents the first step at which glucose utilization is controlled in muscles and adipose tissue (Simpson \& Cushman, 1986), whereas in the liver glucose transport is not thought to be rate-limiting for glucose metabolism in normal conditions. In muscle and fat, glucose transport is acutely stimulated by insulin (Simpson \& Cushman, 1986), but in the liver glucose transport is not sensitive to insulin (Williams et al., 1968; Bauer \& Heldt, 1977). More recently, it has been shown that glucose uptake and release required a family of membrane facilitated-diffusion glucose transporters which are expressed in a tissue-specific manner (Burant et al., 1991). In muscle and fat, GLUT-4 is the main isoform of glucose transporters (Burant et al., 1991). In adipose tissue the concentrations of GLUT-4 protein and mRNA are markedly decreased after 2-3 weeks of diabetes, and they are restored by insulin therapy (Berger et al., 1989; Garvey et al., 1989; Sivitz et al., 1989), whereas in skeletal muscle the concentrations of GLUT-4 protein and mRNA are marginally altered (Garvey et al., 1989; Kahn et al., 1989; Bourey et al., 1990). In liver, GLUT-2 is the main isoform of glucose transporters (Thorens et al., 1988). Much less information is available concerning the expression of GLUT-2 in liver of diabetic rats, and the results are somewhat contradictory. It has been reported that the concentrations of GLUT- 2 protein and mRNA were increased 1.6-2-fold after 2-3 weeks of diabetes in rats (Oka et al., 1990; Yamamoto et al., 1991) and that insulin therapy for 5 days restored the concentrations of GLUT-2 protein and mRNA to the levels of non-diabetic rats (Oka et al., 1990). In contrast, GLUT-2 protein and mRNA were marginally affected after 2-3 weeks of diabetes and were not significantly modified by insulin therapy for 1 week (Thorens et al., 1990). The aim of the present study was to investigate the early effect of streptozotocin (STZ)-induced diabetes on GLUT-2 mRNA in liver and to determine the relative role of hyperglycaemia and hypoinsulinaemia in these changes. The expression of two enzymes involved in gluconeogenesis, phosphoenolpyruvate carboxykinase (PEPCK; EC 4.1.1.32), and glycolysis, glucokinase (GK; EC 2.7.1.1), was studied in parallel.

\section{EXPERIMENTAL}

\section{Animals}

Male Wistar rats $(250 \mathrm{~g})$ bred in our laboratory were housed at $24^{\circ} \mathrm{C}$ with light from 07:00 to 19:00 h. They had free access to water and chow pellets (65\% carbohydrate, $11 \%$ fat, $24 \%$ protein; \% of energy). The studies were performed on conscious rats $24 \mathrm{~h}$ after implantation of catheters into the two jugular veins under pentobarbital anaesthesia $(50 \mathrm{mg} / \mathrm{kg}$ body $\mathrm{wt})$. Immediately after surgery, rats were randomly distributed into four different groups and housed in individual cages.

Group 1. This group of rats had free access to food and water. The rats were killed at 08:00 h. This group was termed as 'fed' control rats.

Group 2. This group of rats was injected with STZ (Sigma, St. Louis, MO, U.S.A.) through the left jugular vein, at a dose of $65 \mathrm{mg} / \mathrm{kg}$ body wt. Rats had free access to food and water and were killed $6,18,30,48$ or $72 \mathrm{~h}$ after the STZ injection. This group was termed 'diabetic' rats.

Group 3. A group of diabetic rats was infused intravenously with phlorizin (Sigma) at a variable rate: $0.5-2 \mathrm{~g} /$ day per $\mathrm{kg}$ 
Table 1. Changes in portal blood glucose, plasma insulin and plasma glucagon concentrations after injection of STZ (65 mg/kg, intravenous)

Values are means \pm S.E.M. from 4-6 animals in each group. Some diabetic rats were infused with either phlorizin (STZ + PHLO) from 18 to $72 \mathrm{~h}$, or insulin (STZ + INS) from 18 to $48 \mathrm{~h}$, and were compared with their respective diabetic rats (STZ $72 \mathrm{~h}$ and STZ $48 \mathrm{~h}$ ). Some insulin-infused diabetic rats had their insulin infusion stopped after $48 \mathrm{~h}$. They were studied 6 and $30 \mathrm{~h}$ after insulin withdrawal. *Difference significantly different $(P<0.05)$ from control values. †Difference significantly different $(P<0.05)$ from STZ $72 \mathrm{~h}$. †Difference significantly different $(P<0.05)$ from STZ 48 h. §Difference significantly different $(P<0.05)$ from STZ + INS.

\begin{tabular}{|c|c|c|c|c|c|c|c|c|c|c|}
\hline & \multirow[b]{2}{*}{ Controls } & \multicolumn{5}{|c|}{ Time after STZ } & \multirow{2}{*}{$\begin{array}{c}\mathrm{STZ}+\mathrm{PHLO} \\
72 \mathrm{~h}\end{array}$} & \multirow{2}{*}{$\begin{array}{c}\text { STZ + INS } \\
\quad 48 \mathrm{~h}\end{array}$} & \multicolumn{2}{|c|}{$\begin{array}{l}\text { Time after insulin } \\
\text { withdrawal }\end{array}$} \\
\hline & & $6 \mathrm{~h}$ & $18 \mathrm{~h}$ & $30 \mathrm{~h}$ & $48 \mathrm{~h}$ & $72 \mathrm{~h}$ & & & $6 \mathrm{~h}$ & $30 \mathrm{~h}$ \\
\hline $\begin{array}{l}\text { Portal blood } \\
\text { glucose (mmol/l) }\end{array}$ & $5.1 \pm 0.4$ & $1.4 \pm 0.4^{*}$ & $4.4 \pm 0.5$ & $17.2 \pm 1.9^{*}$ & $21.3 \pm 1.6^{*}$ & $26.9 \pm 1.5^{*}$ & $6.4 \pm 0.5 \dagger$ & $6.6 \pm 0.3 \ddagger$ & $18.1 \pm 1.8 \S$ & $22.8 \pm 1.9 \S$ \\
\hline $\begin{array}{l}\text { Portal plasma } \\
\text { insulin }(\mu- \\
\text { units } / \mathrm{ml})\end{array}$ & $38 \pm 5$ & $270 \pm 32^{*}$ & $45 \pm 6$ & $7 \pm 2^{*}$ & $<5^{*}$ & $<5^{*}$ & $<5$ & $40 \pm 8 \ddagger$ & $<5 \S$ & $<5 \S$ \\
\hline $\begin{array}{l}\text { Portal plasma } \\
\text { glucagon }(\mathrm{ng} / \mathrm{ml})\end{array}$ & $210 \pm 35$ & $225 \pm 38$ & $410 \pm 48^{*}$ & $315 \pm 27^{*}$ & $302 \pm 46$ & $215 \pm 19$ & $280 \pm 25$ & $220 \pm 25$ & $275 \pm 27$ & $335 \pm 42 \S$ \\
\hline
\end{tabular}

from the $18 \mathrm{~h}$ after STZ injection to $72 \mathrm{~h}$, to maintain their blood glucose level in the normal range. They had free access to food and water during the experimental period. This group was termed 'phlorizin-treated diabetic' rats.

Group 4. A group of STZ-diabetic rats was infused intravenously with insulin (Actrapid; Novo, Copenhagen, Denmark) at a constant rate, 0.25 unit/h per $\mathrm{kg}$, from $18 \mathrm{~h}$ after STZ injection to $48 \mathrm{~h}$, to maintain their blood glucose level in the normal range. They had free access to food and water during the experimental period. This group was termed 'Insulin-treated diabetic' rats. In some of these insulin-treated diabetic rats, insulin infusion was stopped after $48 \mathrm{~h}$. The rats were killed 6 or $30 \mathrm{~h}$ after insulin withdrawal.

\section{Monitoring of blood glucose and plasma insulin and glucagon levels}

Blood glucose and plasma insulin were monitored daily throughout the experimental period in untreated, phlorizintreated and insulin-treated diabetic rats. Blood glucose was routinely monitored by the glucose oxidase method with a Beckman glucose analyser (Beckman BGA2). Plasma insulin and glucagon concentrations were determined by radioimmunoassay as described previously (Girard et al., 1973).

\section{Killing of animals and tissue sampling}

Rats were anaesthetized by an intraperitoneal injection of pentobarbital ( $60 \mathrm{mg} / \mathrm{kg}$ body wt.). Blood was sampled from the portal vein and collected in the presence of 2000 units of aprotinin $/ \mathrm{ml}$ of blood and EDTA $(0.01 \mathrm{M})$. Blood was immediately centrifuged at $4{ }^{\circ} \mathrm{C}$ and the plasma was frozen at $-20^{\circ} \mathrm{C}$ until insulin, glucagon and glucose determinations. After blood sampling, the liver was rapidly removed, rinsed out in $0.9 \% \mathrm{NaCl}$, wiped and frozen at $-80^{\circ} \mathrm{C}$.

\section{Quantification of GLUT-2, GK and PEPCK mRNAs}

Total RNAs were isolated from liver by the guanidine thiocyanate method (Chomczynski \& Sacchi, 1987). The concentration of RNA was determined by the $A_{260}$, and the RNA solutions were stored at $-80^{\circ} \mathrm{C}$ until use. All samples had an $A_{260} / A_{280}$ ratio of about 2.0. For Northern-blot analyses, total RNAs $(20 \mu \mathrm{g})$ were denatured in a solution containing $2.2 \mathrm{mM}$ formaldehyde and $50 \%(\mathrm{v} / \mathrm{v})$ formamide by heating at $95^{\circ} \mathrm{C}$ for 2 min, size-fractionated by electrophoresis and transferred to a nylon membrane. The GLUT-2 cDNA probe (Thorens et al., 1988); the PEPCK cDNA probe (Yoo-Warren et al., 1981) and the GK cDNA probe (Iynedjian et al., 1987) were gifts from Dr.
Bernard Thorens, Dr. Richard Hanson and Dr. Patrick Iynedjian. Probes were labelled with $\left[{ }^{32} \mathrm{P}\right] \mathrm{dCTP}$ with the Multiprime labelling system kit (Amersham International). Hybridizations were performed in solutions containing $42 \%$ deionized formamide, $7.5 \%$ dextran sulphate, $8 \times$ Denhardt's solution, $40 \mathrm{~mm}$ Tris $/ \mathrm{HCl}, \mathrm{pH} 7.5$, and $1 \% \mathrm{SDS}$, at $42^{\circ} \mathrm{C}$ overnight. The membranes were washed twice for $30 \mathrm{~min}$ each, with $2 \times \mathrm{SSC}$ $(1 \times \mathrm{SSC}=0.15 \mathrm{M}-\mathrm{NaCl} / 15 \mathrm{~mm}$-trisodium citrate, $\mathrm{pH} 7.0) /$ $0.1 \%$ SDS at $42^{\circ} \mathrm{C}$ and twice for $30 \mathrm{~min}$ each with $0.1 \times \mathrm{SSC} / 0.1 \%$ SDS at $55^{\circ} \mathrm{C}$ and exposed for $4-72 \mathrm{~h}$ at $-80^{\circ} \mathrm{C}$ with intensifying screens. Quantification was performed by scanning densitometry.

The Northern blots were hybridized with an oligonucleotide probe representing the sequence $1047-1070$ of rat $18 \mathrm{~S}$ rRNA (Chan et al., 1984) labelled with [ ${ }^{32}$ P]ATP to verify the integrity of RNA and that each lane was loaded with the same amount of total RNA.

\section{Quantification of GLUT-2 by immunoblotting}

Liver was homogenized with a motor-driven Teflon pestle at $4{ }^{\circ} \mathrm{C}$ in $0.3 \mathrm{M}$-sucrose $/ 3 \mathrm{~mm}$-dithiothreitol/0.26 unit of aprotinin (Sigma)/ml, 0.1 mM-phenylmethanesulphonyl fluoride at pH 7.4 $(1: 10, \mathrm{w} / \mathrm{v})$. Liver membranes were prepared as described by Thorens et al. (1990). Membranes were resuspended in Laemmli (1970) buffer containing $5 \%$ SDS. Samples $(100 \mu \mathrm{g})$ of membrane protein were resolved by SDS/PAGE (10\% gels) and transferred to nitrocellulose filters (Thorens et al., 1990). Equivalent loading and transfer of proteins from all lanes of the gel was verified by Ponceau Red staining of the nitrocellulose filters and Coomassie Blue staining of the gels. Protein was blotted with a polyclonal antiserum prepared against GLUT-2 (gift from Dr. B. Thorens, University of Lausanne, Switzerland) followed by ${ }^{125}$ I-Protein A (Amersham International, Amersham, Bucks., U.K.). Protein concentration was determined by the Bio-Rad (Munich, Germany) assay with BSA as standard.

\section{Statistical analysis}

Results are expressed as means \pm S.E.M. Statistical analysis was performed by Student's $t$ test for unpaired data.

\section{RESULTS}

Time course of changes in blood glucose and plasma insulin and glucagon concentrations

Fed non-diabetic rats were used as controls. Blood glucose and 
(a) GLUT-2

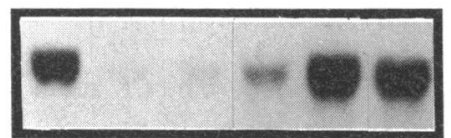

GK

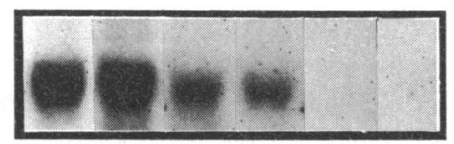

PEPCK

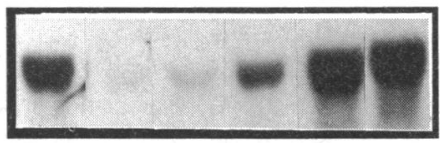

18S rRNA
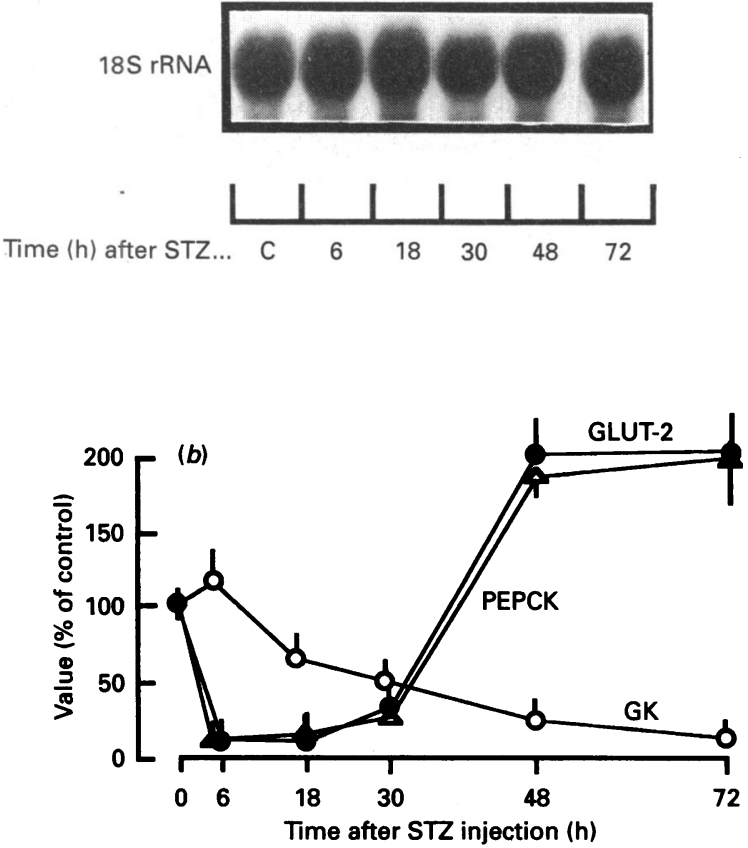

Fig. 1. Time course of changes in liver GLUT-2, GK and PEPCK mRNAs in rats injected with STZ

(a) A representative autoradiograph of Northern blots of liver GLUT-2, GK and PEPCK mRNA is presented. (6 controls) $(b)$ mRNA was quantified by scaning densitometry of Northern blots. Results are expressed as means \pm S.E.M. of 4-6 rats in each group.

The values in non-diabetic rats were taken as $100 \%$.
GLUT-2 mRNA

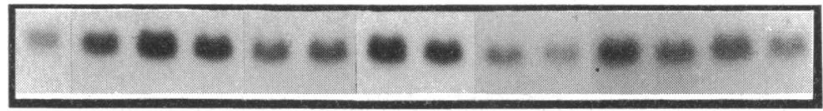

GK mRNA

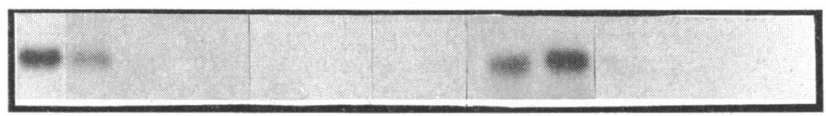

PEPCK MRNA

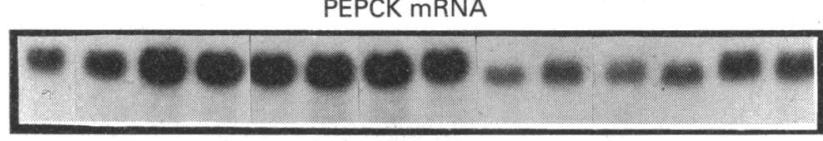

18S rRNA

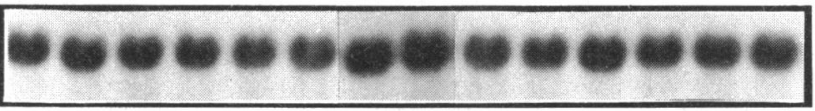

\begin{tabular}{|c|c|c|c|c|c|}
\hline \multirow[t]{2}{*}{ Controls } & \multirow{2}{*}{$\begin{array}{l}\text { STZ } \\
72 \mathrm{~h}\end{array}$} & \multirow{2}{*}{$\begin{array}{c}\text { STZ } \\
+ \\
\text { PHLO }\end{array}$} & \multirow{2}{*}{$\begin{array}{l}\text { STZ } \\
48 \mathrm{~h}\end{array}$} & \multirow{2}{*}{$\begin{array}{c}\text { STZ } \\
+ \\
\text { INS }\end{array}$} & 30 \\
\hline & & & & & $\begin{array}{c}\text { Time (h) } \\
\text { after } \\
\text { insulin } \\
\text { withdrawal }\end{array}$ \\
\hline
\end{tabular}

Fig. 2. Representative autoradiograph of Northern blots of liver GLUT-2, GK and PEPCK mRNA in non-diabetic and diabetic rats

Some diabetic rats were infused either with phlorizin (STZ + PHLO) from 18 to $72 \mathrm{~h}$ or with insulin (STZ+INS) from 18 to $48 \mathrm{~h}$ and were compared with the corresponding diabetic rats (STZ $72 \mathrm{~h}$ and STZ $48 \mathrm{~h}$ ). Some insulin-infused diabetic rats had their insulin infusion stopped after $48 \mathrm{~h}$. They were studied 6 and $30 \mathrm{~h}$ after insulin withdrawal. Two Northern blots for each condition are presented.

plasma insulin and glucagon concentrations in control rats were considered as the initial value during the time-course experiments.

Diabetic rats. At $6 \mathrm{~h}$ after STZ injection, a transient phase of portal hyperinsulinaemia and hypoglycaemia occurred, followed from $30 \mathrm{~h}$ onwards by the typical portal hyperglycaemia and insulinopenia of diabetic rats (Table 1).

To verify that STZ-injected rats were unable to secrete insulin, a glucose-induced insulin-secretion test was performed $30 \mathrm{~h}$ after STZ injection. A glucose solution $(200 \mathrm{mg} / \mathrm{g}$ body wt.) was injected through the left jugular vein. Blood $(300 \mu \mathrm{l})$ was sampled from the right jugular vein before and $5 \mathrm{~min}$ after glucose injection. Blood was immediately centrifuged, and plasma was frozen at $-20^{\circ} \mathrm{C}$ until plasma glucose and insulin

Table 2. Quantification by scanning densitometry of Northern blots of liver GLUT-2, GK and PEPCK mRNA in diabetic rats

Some diabetic rats were infused with either phlorizin (STZ+PHLO) from 18 to $72 \mathrm{~h}$ or insulin (STZ+ INS) from 18 to $48 \mathrm{~h}$ and were compared with their respective diabetic rats (STZ $72 \mathrm{~h}$ and STZ $48 \mathrm{~h}$ ). Some insulin-infused diabetic rats had their insulin infusion stopped after $48 \mathrm{~h}$. They were studied 6 and $30 \mathrm{~h}$ after insulin withdrawal. Results are expressed as means \pm S.E.M. of 4-6 rats in each group. The values in non-diabetic rats were taken as $100 \%$. ${ }^{*}$ Difference significantly different $(P<0.05)$ from control values. $†$ Difference significantly different $(P<0.05)$ from STZ $72 \mathrm{~h}$. ‡Difference significantly different $(P<0.05)$ from STZ $48 \mathrm{~h}$. §Difference significantly different $(P<0.05)$ from STZ+INS.

\begin{tabular}{|c|c|c|c|c|c|c|c|}
\hline \multirow[b]{2}{*}{ mRNA } & \multirow[b]{2}{*}{ Controls } & \multicolumn{2}{|c|}{ Time after STZ } & \multirow{2}{*}{$\begin{array}{c}\mathrm{STZ}+\mathrm{PHLO} \\
72 \mathrm{~h}\end{array}$} & \multirow{2}{*}{$\begin{array}{c}\text { STZ + INS } \\
48 \mathrm{~h}\end{array}$} & \multicolumn{2}{|c|}{$\begin{array}{l}\text { Time after insulin } \\
\text { withdrawal }\end{array}$} \\
\hline & & $48 \mathrm{~h}$ & $72 \mathrm{~h}$ & & & $6 \mathrm{~h}$ & $30 \mathrm{~h}$ \\
\hline $\begin{array}{l}\text { GLUT-2 } \\
\text { GK } \\
\text { PEPCK }\end{array}$ & $\begin{array}{l}100 \pm 15 \\
100 \pm 18 \\
100 \pm 8\end{array}$ & $\begin{array}{c}205 \pm 12^{*} \\
<5^{*} \\
195 \pm 15^{*}\end{array}$ & $\begin{array}{c}213 \pm 17^{*} \\
<5^{*} \\
210 \pm 22^{*}\end{array}$ & $\begin{array}{c}111 \pm 12 \dagger \\
<5 \\
220 \pm 25\end{array}$ & $\begin{array}{r}75 \pm 9 \ddagger \\
110 \pm 15 \ddagger \\
73 \pm 12 \ddagger\end{array}$ & $\begin{array}{c}118 \pm 21 \S \\
<5 \S \\
85 \pm 18\end{array}$ & $\begin{aligned} & 180 \pm 26 \S \\
&<5 \S \\
& 203 \pm 17 \S\end{aligned}$ \\
\hline
\end{tabular}



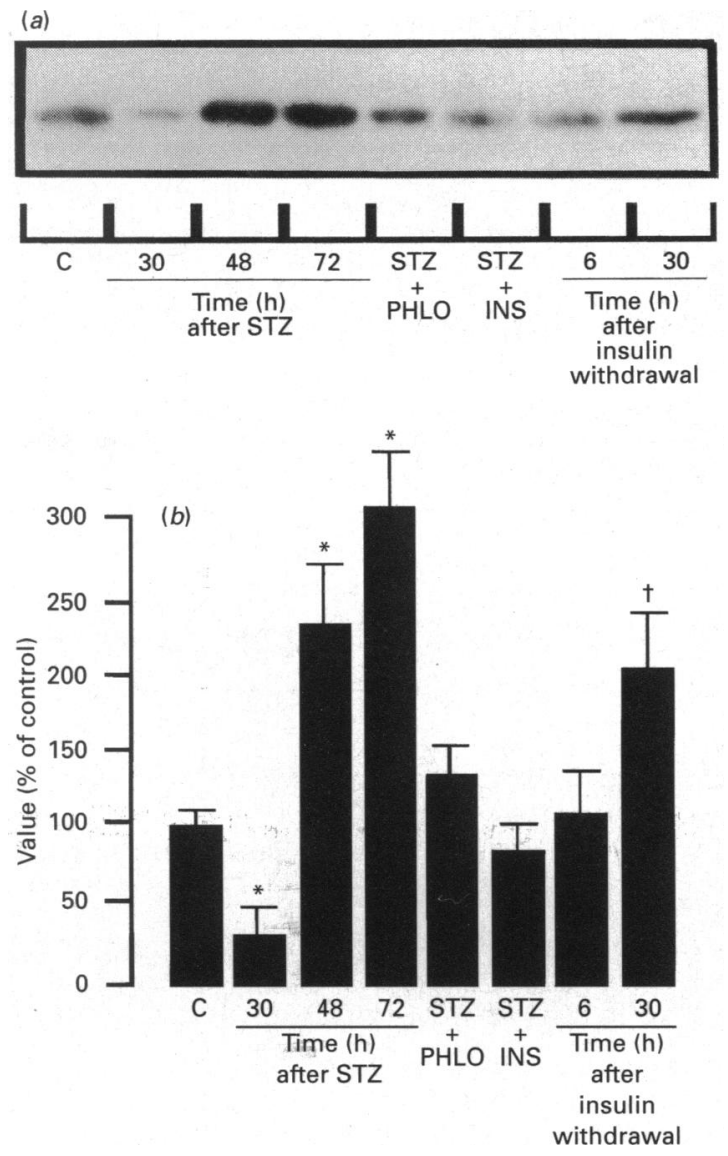

Fig. 3. (a) Representative autoradiograph of Western blots and (b) quantification by scanning densitometry of Western blots of GLUT2 protein in liver membranes from control and diabetic rats

(a) Some diabetic rats were infused with either phlorizin (STZ + PHLO) from 18 to $72 \mathrm{~h}$ or insulin (STZ + INS) from 18 to $48 \mathrm{~h}$ and were compared with the corresponding diabetic rats (STZ $72 \mathrm{~h}$ and STZ $48 \mathrm{~h}$ ). Some insulin-infused diabetic rats had their insulin infusion stopped after $48 \mathrm{~h}$. They were studied 6 and $30 \mathrm{~h}$ after insulin withdrawal. In $(b)$ results are expressed as means \pm S.E.M. of 4-6 rats in each group. The values in non-diabetic rats were taken as $100 \% .{ }^{*}$ Difference significantly different $(P<0.05)$ from control values. †Difference significantly different $(P<0.05)$ from STZ + INS values. Abbreviation: $\mathrm{C}$, control.

determinations. Plasma insulin concentrations in STZ-treated rats injected with glucose remained at the low basal value ( $<5 \mu$-units $/ \mathrm{ml}$ ), despite very high plasma glucose concentration ( $>20 \mathrm{mmol} / \mathrm{l}$ ) (results not shown).

Phlorizin-treated diabetic rats. Some diabetic rats were infused with phlorizin $18 \mathrm{~h}$ after STZ injection. The rate of phlorizin infusion was adjusted to maintain the venous-blood glucose concentration at a mean value of $7.2 \pm 0.4 \mathrm{mmol} / 1$ from $18 \mathrm{~h}$ to $72 \mathrm{~h}$ (Table 1). Portal plasma insulin concentration in phlorizintreated diabetic rats $(<5 \mu$-units $/ \mathrm{ml})$ was not statistically different from the untreated diabetic rats (Table 1).

Insulin-treated diabetic rats. Some diabetic rats were infused with insulin $18 \mathrm{~h}$ after STZ injection. The rate of insulin infusion was adjusted to maintain the blood glucose concentration at a mean value of $6.6 \pm 0.3 \mathrm{mmol} / 1$ from $18 \mathrm{~h}$ to $48 \mathrm{~h}$ (Table 1 ). The mean portal plasma insulin concentration reached during insulin infusion was $40 \pm 8 \cdot \mu$-units $/ \mathrm{ml}$, i.e. a physiological concentration (Table 1). When insulin infusion was stopped, a rapid decrease in portal plasma insulin concentration and a marked hyperglycaemia occurred (Table 1). This allowed us to study short-term effects of insulin deprivation and hyperglycaemia on GLUT-2, GK and PEPCK mRNA concentrations.

\section{Changes in GLUT-2, GK and PEPCK mRNA concentrations}

GLUT-2, GK and PEPCK mRNA concentrations in liver of fed non-diabetic rats were used as controls. These values were considered as $100 \%$ and were used as initial value during the time-course experiments. GLUT-2 and PEPCK mRNA concentrations decreased by $90 \%$ as soon as $6 \mathrm{~h}$ after STZ injection, in parallel with the transient hyperinsulinaemia (Figs. $1 a$ and $1 b$ ). They increased after $30 \mathrm{~h}$ to reach a level 2 -fold higher than in non-diabetic rats after $48 \mathrm{~h}$ and later (Figs. $1 a$ and $1 b)$. In contrast, GK mRNA concentrations remained elevated $6 \mathrm{~h}$ after STZ injection and decreased rapidly after $18 \mathrm{~h}$ to reach very low level after $48 \mathrm{~h}$ (Figs. $1 a$ and $1 b$ ).

Normalization of blood glucose concentration by phlorizin treatment restored liver GLUT-2 mRNA concentration to that found in non-diabetic rats (Fig. 2, Table 2), but did not modify the high level of liver PEPCK mRNA and the low level of GK mRNA found in diabetic rats (Fig. 2, Table 2).

In insulin-treated diabetic rats, liver GLUT-2 and PEPCK mRNA concentrations were $25 \%$ of those in untreated diabetic rats, and GK mRNA was markedly induced (Fig. 2, Table 2). At $6 \mathrm{~h}$ after insulin infusion was withdrawn, GLUT-2 and PEPCK mRNA concentrations rapidly increased and GK mRNA concentrations disappeared (Fig. 2, Table 2).

\section{Changes in GLUT-2 protein concentration}

GLUT-2 protein concentration was decreased by $70 \%$ after $30 \mathrm{~h}$ and then increased to a level 2-3-fold higher than the control values (Figs $3 a$ and $3 b$ ). Phlorizin and insulin treatment of diabetic rats prevented the increase in GLUT-2 protein concentration (Figs. $3 a$ and $3 b$ ). When insulin treatment was stopped, an increase in GLUT-2 protein concentration was observed after $30 \mathrm{~h}$ (Figs. $3 a$ and $3 b$ ).

\section{DISCUSSION}

Glucose homoeostasis is markedly disturbed in the liver of diabetic rats. Our data confirm that the well-known hyperglycaemia, hyperglucagonaemia and hypoinsulinaemia that occur $30 \mathrm{~h}$ after STZ injection in diabetic rats is associated with a decrease in liver GK mRNA (Iynedjian et al., 1988; Spence, 1983; Sibrowski \& Seitz, 1984), an increase in liver PEPCK mRNA (Beale et al., 1984) and a slight increase or an unchanged level of liver GLUT-2 mRNA (Thorens et al., 1988; Oka et al., 1990; Yamamoto et al., 1991). Time-course experiments show that early portal hyperinsulinaemia and hypoglycaemia in STZtreated rats are accompanied by a decrease in GLUT- 2 mRNA and PEPCK and by a slight increase in GK mRNA. This is in agreement with the well-known effect of hyperinsulinaemia on GK and PEPCK expression (Cimbala et al., 1982; Spence, 1983; Beale et al., 1984; Iynedjian et al., 1988). The fall in GLUT-2 mRNA in response to hyperinsulinaemia was unexpected from previous work in diabetic rats. Recent experiments from our laboratory have also shown that GLUT- 2 mRNA concentrations are decreased by hyperinsulinaemia during a $6 \mathrm{~h}$ euglycaemic clamp performed in $24 \mathrm{~h}$-fasted rats (Postic et al., 1992). Moreover, the early fall in GLUT-2 mRNA is followed by a decrease in GLUT-2 protein concentration at $30 \mathrm{~h}$. Thus data strongly suggest that euglycaemic hyperinsulinaemia inhibits liver GLUT-2 gene expression. About $30 \mathrm{~h}$ after STZ injection, PEPCK and GLUT-2 mRNA increase, and GK mRNA decreases, to reach after $48 \mathrm{~h}$ the levels reported previously in the liver of diabetic rats (Spence, 1983; Beale et al., 1984; Sibrowski \& Seitz, 1984; Iynedjian et al., 1988). After 48 and $72 \mathrm{~h}$ 
GLUT-2 protein levels are increased in liver of diabetic rats. To study the relative roles of hyperglycaemia and hypoinsulinaemia in the changes in GLUT-2 mRNA and protein levels, we have treated diabetic rats with phlorizin and insulin. The 2-fold increase in GLUT-2 mRNA and protein in liver of diabetic rats is corrected by normalization of blood glucose concentration by phlorizin, suggesting that hyperglycaemia stimulates GLUT-2 gene expression. This is in agreement with recent experiments showing that GLUT-2 mRNA is increased in the presence of high glucose concentrations in cultured rat hepatocytes (Asano et al., 1992) and by experiments in vivo in which liver GLUT-2 mRNA does not decrease in response to hyperinsulinaemia in $24 \mathrm{~h}$-fasted rats clamped at hyperglycaemic levels (Postic et al., 1992). The inhibitory effect of insulin on GLUT-2 gene expression is further underlined by the fact that physiological insulin infusion decreases GLUT-2 mRNA and protein in the liver of diabetic rats, the level reached being $50 \%$ lower than in phlorizin-treated diabetic rats. Moreover, when insulin infusion was stopped, GLUT-2 mRNA and protein concentrations rapidly returned to 'diabetic' levels.

The correction of hyperglycaemia by phlorizin in diabetic rats did not modify GK and PEPCK mRNA. Previous studies in cultured rat hepatocytes have shown that the expression of GK mRNA was not affected by glucose concentrations (Iynedjian et al., 1989; Narkewicz et al., 1990), but that PEPCK gene expression was inhibited by high glucose concentrations (Meyer et al., 1991). However, in the latter study, very high glucose concentrations were used, and the physiological meaning of that experiment is not obvious. The regulatory effects of insulin on PEPCK and GK gene expression are further underlined by the fact that physiological insulin infusion decreases PEPCK mRNA and increases GK mRNA in the liver of diabetic rats. Moreover, when insulin infusion was stopped, PEPCK mRNA rapidly increased, and GK mRNA rapidly decreased, to diabetic levels.

We express our gratitude to Danièle Chamereau for taking care of the animals, Patricia Meralli for secretarial assistance and Catherine Postic for helpful criticisms of this manuscript.

\section{REFERENCES}

Asano, T., Katagiri, H., Tsukuda, K., Lin, J. L., Ishihara, Y. \& Oka, Y. (1992) Diabetes 41, 22-25

Bauer, H. \& Heldt, H. W. (1977) Eur. J. Biochem. 74, 397-403
Beale, E. G., Andreone, T., Koch, S., Granner, S. M. \& Granner, D. K. (1984) Diabetes 33, 328-332

Berger, J., Biswas, C., Vicario, P. P., Strout, H. V., Saperstein, R. \& Pilch, P. F. (1989) Nature (London) 340, 70-72

Bourey, R. E., Koranyi, L., James, D. E., Mueckler, M. \& Permutt, M. A. (1990) J. Clin. Invest. 86, 542-547

Burant, C. F., Sivitz, W. I., Fukumoto, H., Kayano, T., Nagamatsu, S., Seino, S., Pessin, J. E. \& Bell, G. I. (1991) Recent Prog. Horm. Res. 47, 349-388

Chan, Y. L., Gutell, R., Noller, H. F. \& Woll, I. G. (1984) J. Biol. Chem. 259, 224-230

Chomczynski, P. \& Sacchi, N. (1987) Anal. Biochem. 162, 156-159

Cimbala, M. A., Lamers, W. H., Nelson, K., Monahan, J. E., YooWarren, H. \& Hanson, R. W. (1982) J. Biol. Chem. 257, 7629-7636

Garvey, W. T., Huecksteadt, T. P. \& Birnbaum, M. J. (1989) Science $245,60-63$

Girard, J., Cuendet, G. S., Marliss, E. B., Kervran, A., Rieutort, M. \& Assan, R. (1973) J. Clin. Invest. 52, 3190-3200

Iynedjian, P. B., Ucla, C. \& Mach, B. (1987) J. Biol. Chem. 262, $6032-6038$

Iynedjian, P. B., Gjinovci, A. \& Renold, A. E. (1988) J. Biol. Chem. 263, 740-744

Iynedjian, P. B., Jotterand, D., Nouspikel, T., Asfari, M. \& Pilot, P. K. (1989) J. Biol. Chem. 264, 21824-21829

Kahn, B. B., Charron, M. J., Lodish, H. F., Cushman, S. W. \& Flier, J. S. (1989) J. Clin. Invest. 84, 404-411

Laemmli, U. K. (1970) Nature (London) 227, 680-685

Meyer, S., Hoppner, W. \& Seitz, H. J. (1991) Eur. J. Biochem. 202, 985-991

Narkewicz, M. R., Iynedjian, P. B., Ferré, P. \& Girard, J. (1990) Biochem. J. 271, 585-589

Oka, Y., Asano, T., Shibasaki, Y., Lin, J. L., Tsukuda, K., Akanuma, Y. \& Takaku, F. (1990) Diabetes 39, 441-446

Postic, C., Burcelin, R., Leturque, A., Pégorier, J. P., Loizeau, M. \& Girard, J. (1992) Diabetologia 35, A44

Sibrowski, W. \& Seitz, H. J. (1984) J. Biol. Chem. 259, 343-346

Simpson, I. A. \& Cushman, S. W. (1986) Annu. Rev. Biochem. 55, 1059-1989

Sivitz, W. I., de Sautel, S. L., Kayano, T., Bell, G. I. \& Pessin, J. E. (1989) Nature (London) 340, 72-74

Spence, J. T. (1983) J. Biol. Chem. 258, 9143-9146

Thorens, B., Sarkar, H. K., Kaback, H. R. \& Lodish, H. F. (1988) Cell $55,281-290$

Thorens, B., Flier, J. S., Lodish, H. F. \& Kahn, B. B. (1990) Diabetes 39, 712-719

Williams, T. F., Exton, J. H., Park, C. R. \& Regen, D. M. (1968) Am. J. Physiol. 215, 1200-1209

Yamamoto, T., Fukumoto, H., Koh, G., Yano, H., Yasuda, K., Masuda, K., Ikeda, H., Imura, H. \& Seino, Y. (1991) Biochem. Biophys. Res. Commun. 175, 995-1002

Yoo-Warren, H., Cimbala, M. A., Felz, K., Monahan, J. E., Leis, J. P. \& Hanson, R. W. (1981) J. Biol. Chem. 256, 10224-10227

Received 19 March 1992/4 June 1992; received 24 June 1992 